\title{
A METHOD FOR THE DETERMINATION OF AMINO NITROGEN AND AMMONIA IN CREAM AND BUTTER. ${ }^{\prime}$
}

\author{
By L. W. Ferris.
}

[ABSTRACT.]

In order to measure the relative proportion of amino nitrogen in milk, cream, buttermilk, and butter, it is desirable to have a procedure that is adaptable to all of these products. A method using picric and acetic acids, devised in the Bureau of Chemistry, has the following advantages:

I. Easy and rapid separation of the proteins and more complex substances from the lower degradation products, principally amino acids.

2. Hydrolysis of proteins during analysis is reduced to a minimum.

3. The filtrate can be held without further change, allowing a reasonable time between preparation of sample and analysis.

4. A correlation between amount of amino nitrogen and quality of sample.

By this procedure the amino nitrogen and ammonia in fourteen samples of fresh butter from sweet cream was found to range from 0.9 to 2.3 , with an average of 1.4 , expressed as percentage of the total nitrogen.

\section{STUDIES ON THE DIGESTIBILITY OF PROTEINS IN VITRO. III. ON THE CHEMICAL NATURE OF THE NUTRITIONAL DEFICIENCIES OF ARACHIN. ${ }^{2}$}

\section{By D. Breese Jones and Henry C. Waterman.}

[ABSTRACT.]

Estimations of the digestibility in vitro of variously treated preparations of arachin (the principal protein of the peanut, Arachis hypogaa) by the method of Waterman and Johns, indicate: ( I) That this protein is incompletely digestible, and that

* Communicated by the Chief of the Bureau.

${ }^{1}$ Published in J. Dairy Sciences, 5, July, 1922, 399.

2 Published in J. Biol. Chem., 50, June, 1922, 357.

VoL. 194, No. 1 I63-48 
this condition is not altered by boiling with water at ordinary pressure or by cooking under a steam pressure of fifteen pounds; and (2) that the nutritional failure of arachin is due to the retention of a considerable part of one or more of the essential animo acids, the most conspicuous of which is histidine, in the indigestible complex. The total amino acid composition of arachin would almost certainly be quite adequate, if it were available.

A direct comparison of the digestibility in vitro of arachin with that of casein and of cooked phaseolin gave the following (average) values for percentage of digested nitrogen, calculated on the basis of the total amino, minus free amino nitrogen: Arachin, 48.5; casein, 61.4; cooked phaseolin, 58.7. The control proteins are known to be sufficiently digestible to be available. An extremely indigestible partial cleavage product, produced by warming arachin with o.I $\mathrm{N}$ sodium hydroxid for two hours and precipitating the unattacked residue with very dilute acid, contained somewhat more than two-thirds of the total histidine, and about two-fifths of the total lysine of the arachin from which it was derived.

The experiments indicate that the incomplete digestibility of arachin is not due to changes brought about by the treatment involved in its isolation, but is a native property of the protein. The high nutritional efficiency of peanut meal is therefore to be attributed to the presence in the meal of sources of amino acids which supply essentials contained in an unavailable form in arachin.

\section{THE PLAGIOCLASE FELDSPARS AS A CASE OF ATOMIC ISOMORPHISM.}

\section{By Edgar T. Wherry.}

[ABSTRACr.]

THE structural formula viewpoint is incapable of accounting for the isomorphism of the plagioclases, the arithmetical viewpoint mistakes a corollary for a cause, and only the atomic isomorphism viewpoint really corresponds to the data. As sodium is indicated by X-ray measurement to occupy approximately the same volume as calcium, and aluminium as silicon, the two feld-

\footnotetext{
'Published in Am. Mineralogist, 7, July, 1922, 113.
} 